\title{
COMBINING ABILITY FOR CARBOHYDRATE COMPONENTS ASSOCIATED WITH CONSUMER PREFERENCES IN TROPICAL SWEET AND WAXY CORN DERIVED FROM EXOTIC GERMPLASM
}

\author{
Aphakorn FUENGTEE ${ }^{1}$, Abil DERMAIL ${ }^{1}$, Sakunkan SIMLA3, Kamol LERTRAT ${ }^{2}$, \\ Jirawat SANITCHON ${ }^{1,2}$, Sompong CHANKAEW ${ }^{1,2}$, Bhalang SURIHARN ${ }^{1,2 *}$ \\ ${ }^{1}$ Khon Kaen University, Faculty of Agriculture, Department of Agronomy, THAILAND, \\ ${ }^{2}$ Khon Kaen University, Plant Breeding Research Center for Sustainable Agriculture, THAILAND, \\ ${ }^{3}$ Mahasarakham University, Department of Agricultural Technology, Mahasarakham, THAILAND \\ ${ }^{*}$ Corresponding author: sphala@kku.ac.th
}

Received: 14.05.2020

\begin{abstract}
Vegetable corn with an excellent, balance proportion of kernel carbohydrates in relation to good eating quality appeals to consumers. Sweet-waxy corn hybrid is proposed to improve palatability of traditional cooked waxy corn, well known as synergistic corn. We determined genetic effects of sugars, phytoglycogen, total starch, and amylopectin and estimated general combining ability of parents for these traits. Three sweet corn lines assigned as female were crossed with eight waxy corn lines as male following the North Carolina II. About 11 parents, $24 F_{1}$ progenies, and 3 checks were evaluated in randomized complete block design with three replications in two seasons between 2017-2018. Then, entry means of 38 genotypes was clustered with dendogram. Additive effect was important for favored kernel carbohydrates except for phytoglycogen. Two sweet corn lines 101LBW and 101LTSC-10 were proposed as broad-based testers for total sugar and sugar fractions, whereas a waxy corn line KVMON for total starch and amylopectin. Cluster analysis based on amylopectin, total sugar, and phytoglycogen was reliable to discriminate corn genotypes into seven major groups, and two sweet-waxy corn $F_{1}$ hybrids 101LTSC-10/C13-1 and 101LTSC-10/KV3473 corresponding to our selection criteria were identified. Implications in plant breeding and suggestions for further investigations are discussed.
\end{abstract}

Keywords: Amylopectin, hybrid breeding, maize, palatability improvement, phytoglycogen, total sugar

\section{INTRODUCTION}

Waxy corn (Zea mays L. ceratina) is a popular, staple crop consumed as vegetable in East and Southeast Asia. In Thailand, waxy corn has been cultivated as a cash crop, and it is harvested at fresh stage and is cooked for daily consumption (Lertrat and Thongnarin, 2008). Nowadays, the increasing consumption is followed by higher preference of more palatable cooked waxy corn such as stickiness and soft tenderness (Jung et al., 2005). These attributes are associated with high amylopectin content (Fergason, 2001) and thin pericarp (Jung et al., 2009; So, 2019). Meanwhile, consumer preferences in relation to eating quality of sweet corn are flavor, texture, and aroma (Wann et al., 1971; Flora and Wiley, 1974). Flavor is determined by sweetness, kernel sucrose content, juiciness, and total starch (Azanza et al., 1996a; Reyes et al., 1982), whereas kernel texture is made of pericarp tenderness (Bailey and Bailey, 1938) and phytoglycogen content (Swiader et al., 1992).

Traditional waxy corn is recognized for high stickiness due to predominance of amylopectin content up to $95 \%$
(Fergason, 2001) with poor sweetness and low sugars (Simla et al., 2016). Sweet-waxy corn hybrid is proposed to improve palatability of traditional cooked waxy corn by applying the synergistic effect of sweet gene combinations (Simla et al., 2009) and maximizing the proportion of sweet kernels among segregating $\mathrm{F}_{2}$ kernels of individual $\mathrm{F}_{1}$ ear through Mendelian ratio (Lertrat and Thongnarin, 2008; Simla et al., 2016). The eating quality of vegetable corn can be improved by phenotypic selection based on kernel carbohydrates (Azanza et al., 1996a). Three of seven chemical properties observed in our study namely amylopectin, total sugar, and phytoglycogen are assigned as selection criteria.

Waxy corn is domesticated in Southeast Asia including Thailand (Stamp et al., 2016) from wild-type plants in China (Tian et al., 2009). The introduction of exotic corn germplasm differed in climatic regions is expected to expand the genetic diversity in tropical corn breeding (Menkir et al., 2006). The concept of general combining ability (GCA) and specific combining ability (SCA) for inbred and hybrid selections, respectively 
(Sprague and Tatum, 1942) have been common in corn hybrid breeding to date. While the GCA is correlated to additive genetic effect, the SCA is associated with nonadditive effects (Falconer, 1989; Rojas and Sprague, 1952). The North Carolina II or factorial mating design (Comstock and Robinson, 1948) is suitable for hybrid formation that involves many parents and avoids intragroup crosses (Hallauer et al., 2010). Previous studies of combining ability analysis and gene action have been conducted with sweet corn $\mathrm{x}$ sweet corn for total sugar, sucrose, phytoglycogen, and starch (Has and Has, 2009; Khanduri et al., 2010; Rosenbrook and Andrew, 1971) and waxy corn $\mathrm{x}$ waxy corn for starch pasting viscosity properties (Ketthaisong et al., 2014).

Incorporation of sweet genes su/sh2/bt to $w x$ background through two genes combinations has been investigated among sweet and waxy corn lines (Simla et al., 2016); however, combining ability analysis on these traits of interest by mating scheme between sweet corn $x$ waxy corn has not been reported. Therefore, this current study aimed to estimate the GCA of eleven corn inbred lines for kernel carbohydrates and to identify favored sweet-waxy corn $F_{1}$ progenies with an excellent, balance proportion of amylopectin, total sugar, and phytoglycogen. Information obtained in this study helps breeder working with synergistic sweet-waxy corn hybrids.

\section{MATERIALS AND METHODS}

\section{Plant material and mating design}

Eleven parental lines comprised of three sweet corn breeding lines and eight waxy corn breeding lines were used in this study (Table 1). Almost tested lines were derived from different origins; however, they had good adaptation to the tropical zone of Thailand. One of three sweet corn lines was 101LBW with two-gene combination (btbtSh2Sh2wxwx), whereas other two lines were 101LTSC-4 and 101LTSC-10 with three-gene combination (btbtsh2sh2wxwx). Meanwhile, all tested waxy corn lines were equipped with common waxy background (BtBtSh2Sh2wxwx). These lines were crossed according to North Carolina Design II by assigning sweet corn lines as female and waxy corn lines as male to produce $24 \mathrm{~F}_{1}$ progenies. These progenies were expected to possess gene combination of both sweet and waxy genes segregated among kernels within an ear. Also, three commercial F1 hybrids KNW, SW25, and NTT were used as check. These checks belonged to sweet waxy corn hybrids with slightly different proportion of eating quality.

Table 1. Sweet corn and waxy corn inbred lines used as parents.

\begin{tabular}{|c|c|c|c|c|}
\hline Name & Phenotype & Genotype & Origin $^{a}$ & Climatic zone \\
\hline $\begin{array}{l}\text { Females } \\
\text { 101LBW } \\
\text { 101LTSC-4 } \\
\text { 101LTSC-10 }\end{array}$ & $\begin{array}{l}\text { Supersweet corn } \\
\text { Supersweet corn } \\
\text { Supersweet corn }\end{array}$ & $\begin{array}{l}\text { btbt Sh2Sh2 wxwx } \\
b t b t \operatorname{sh} 2 \operatorname{sh} 2 w x w x \\
b t b t \operatorname{sh} 2 \operatorname{sh} 2 w x w x\end{array}$ & $\begin{array}{c}\text { THA } \\
\text { THA/USA } \\
\text { THA/USA } \\
\end{array}$ & $\begin{array}{c}\text { Tropical } \\
\text { Tropical/Temperate } \\
\text { Tropical/Temperate }\end{array}$ \\
\hline $\begin{array}{l}\text { Males } \\
\text { Y18 } \\
\text { C13-1 } \\
\text { HNO2 } \\
\text { HJ } \\
\text { OWX13 } \\
\text { KVMON } \\
\text { KV3473 } \\
\text { KNM102 } \\
\end{array}$ & $\begin{array}{l}\text { Waxy corn } \\
\text { Waxy corn } \\
\text { Waxy corn } \\
\text { Waxy corn } \\
\text { Waxy corn } \\
\text { Waxy corn } \\
\text { Waxy corn } \\
\text { Waxy corn } \\
\end{array}$ & $\begin{array}{l}\text { BtBt Sh2Sh2 wxwx } \\
\text { BtBt Sh2Sh2 wxwx } \\
\text { BtBt Sh2Sh2 } w x w x \\
\text { BtBt Sh2Sh2 } w x w x \\
\text { BtBt Sh2Sh2 } w x w x \\
\text { BtBt Sh2Sh2 } w x w x \\
\text { BtBt Sh2Sh2 } w x w x \\
\text { BtBt Sh2Sh2 } w x w x\end{array}$ & $\begin{array}{c}\text { CHI } \\
\text { CHI } \\
\text { CHI } \\
\text { CHI } \\
\text { THA } \\
\text { THA/USA } \\
\text { THA/USA } \\
\text { THA } \\
\end{array}$ & $\begin{array}{c}\text { Subtropical } \\
\text { Subtropical } \\
\text { Subtropical } \\
\text { Subtropical } \\
\text { Tropical } \\
\text { Tropical/Temperate } \\
\text { Tropical/Temperate } \\
\text { Tropical } \\
\end{array}$ \\
\hline
\end{tabular}

${ }^{\mathrm{a}} \mathrm{THA}=$ Thailand; $\mathrm{USA}=$ United States of America; $\mathrm{CHI}=$ China

\section{Experimental design}

11 parental lines, $24 \mathrm{~F}_{1}$ progenies, and 3 checks were assigned in a randomized complete block design (RCBD) with three replications and were evaluated in the dry season 2017/2018 and in the rainy season 2018 at Khon Kaen University $\left(16^{\circ} 28^{\prime} 27.7^{\prime \prime}\right.$ N, $102^{\circ} 48^{\prime} 36.5^{\prime \prime}$ E; 190 masl), Thailand. Each plot consisted of 2 rows of $5 \mathrm{~m}$ long with $75 \mathrm{~cm} \times 25 \mathrm{~cm}$ of plant spacing; thus, the plot size was $7.5 \mathrm{~m}^{2}$ with 40 plants within the plot. The crop field managements applied in this experiment was according to the Thailand Department of Agriculture.

\section{Sample preparation and chemical analysis}

At milk stage or 19-20 days after pollination the green corn ears were harvested for quantifying kernel carbohydrates namely total sugar, sucrose, glucose, fructose, phytoglycogen, starch content, and amylopectin content. All harvested ears were derived from controlled sib-pollination to guarantee uniform maturity and genetic purity, and about five ears per plot were selected by following some criteria such as non defective ears with full husk cover. Both procedures for sample preparation and chemical analysis followed Simla et al. (2010) with proper modification. Briefly, the samples were trawled and homogenized in a blender. Each sample in a quantity of $1 \mathrm{~g}$ was loaded in a micro-tube for extraction of sugars, phytoglycogen, and starch, using different extraction solvents. Three fractions of total sugar namely sucrose, glucose, fructose were analyzed with high performance liquid chromatography (HPLC) method (Shimadzu ${ }^{\mathrm{TM}}$ RID 
10A reflextive index detector Japan, Water ${ }^{\mathrm{TM}}$ Temperate Control Module II Water ${ }^{\mathrm{TM}}$, Column Heater Module). Quantification of phytoglycogen was carried out by using phenol-sulfuric colorimetric method with wavelength of $490 \mathrm{~nm}$. Similarly, quantification of amylopectin and total starch was carried out by using the same method with quantification of phytoglycogen except for the absorbed wavelength being $600 \mathrm{~nm}$ instead of $490 \mathrm{~nm}$.

\section{Data analysis}

The mean squares for male and female parents are independent estimates of GCA male and GCA female effects, respectively, whereas mean square for interaction between male and female is an estimate of SCA effect (Hallauer et al., 2010). The statistical model for combining ability analysis followed Singh and Chaudhary (1985) with proper modification regarding North Carolina II multi-environment in AGD-R User's guide manual (Rodríguez et al., 2018). The proportional contributions of males $\left(\mathrm{GCA}_{\mathrm{M}}\right)$, females $\left(\mathrm{GCA}_{\mathrm{F}}\right)$, and their interaction
$\left(\mathrm{SCA}_{\mathrm{M} \times \mathrm{F}}\right)$ to the total sum of squares of hybrid were assumed to determine gene action on targeted traits (Singh and Chaudhary, 1985). Combining ability estimates (GCA and SCA) including their standard errors were calculated following Singh and Chaudhary (1985). Narrow-sense heritability was estimated on the basis of plot means (Holland et al., 2003) and was adjusted to percentage (\%) units. The Pearson correlation coefficient (r) was calculated to estimate the relationship between line per se and GCA, and association among kernel carbohydrates (Figure 1). Dendogram based on hierarchical Ward's clustering method was constructed, derived from a data matrix of 38 genotype means of three attributes namely amylopectin, total sugar, and phytoglycogen as representative criteria associated with consumer preferences for sweet-waxy corn hybrids. Least significant difference (LSD) at $\mathrm{P}<0.05$ was performed to compare each group mean to the respective checks (Gomez and Gomez, 1984).

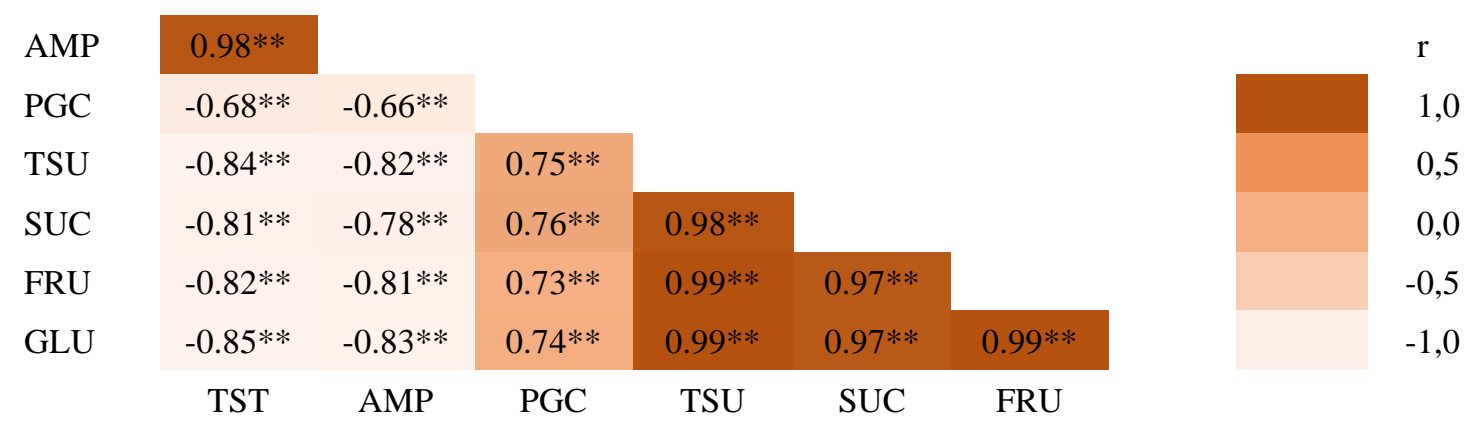

Figure 1. Triangular heat map representing Pearson correlation coefficients (r) among kernel carbohydrate components of sweet and waxy corn genotypes. Means of 38 genotypes (11 parental lines, 24 F1 progenies, and 3 checks) were used as sample size to estimate the correlation. AMP = amylopectyn, $\mathrm{PGC}=$ phytoglycogen, $\mathrm{TSU}=$ total sugar, $\mathrm{SUC}=$ sucrose, FRU $=$ fructose, GLU $=$ glucose, TST $=$ total starch. $* *$ level of significance for $\mathrm{r}$ value at $\mathrm{P}<0.01$

The North Carolina II analysis, narrow-sense heritability, and combining ability estimates for all observed traits were computed by using Analysis of Genetic Designs in R (AGD) version 5.0. software (Rodríguez et al., 2018), whereas linear correlation analysis and mean comparison based on LSD's test by using Statistix 10 (Statistix 10, 2013). Dendogram construction was visualized with JMP Pro software (SAS Institute, 2019).

\section{RESULTS AND DISCUSSION}

North Carolina II analysis, gene action, and heritability

North Carolina II multi-season analysis for total sugar (TSU), sucrose (SUC), glucose (GLU), fructose (FRU), phytoglycogen (PHY), total starch (TSA), and amylopectin (AMY) are presented in Table 2. The influence of season was significant for all observed traits except for GLU. GCA of female was significant for all observed traits except for AMY. The effects of hybrid, GCA of male, SCA, interaction between hybrid and season, and interaction between GCA of female and season were significant for all observed traits. While the interaction between GCA of male and season was significant for all observed traits except for amylopectin, the effect of SCA by season interaction was significant for all traits excluding TSA and AMY.

The significance of hybrid indicated that the genotypic variability on kernel carbohydrates existed, allowing breeders to do selection. In this study, each female has unique recessive allele combination such as brittle (bt) and shrunken-2 (sh2) affecting composition changing of kernel carbohydrates on segregated $F_{2}$ seeds of $F_{1}$ plants. The significance of season, $\mathrm{H} \times \mathrm{S}, \mathrm{GCA}_{\mathrm{F}} \times \mathrm{S}, \mathrm{GCA}_{\mathrm{M}} \times \mathrm{S}$, SCA x $\mathrm{S}$ implied that both performances of inbred lines in hybrid formation and $\mathrm{F}_{1}$ progenies in field trials were obviously influenced by different growing seasons. Previous workers reported the influence of experimental sites differing in soil types and weather conditions on composition changings of both total sugar and the sugar fractions among sweet corn inbred lines with different 
endosperm mutations (Azanza et al., 1996b; Wong et al., 1994). Also, two weather profiles namely temperature (Lu et al., 2013) and solar radiation (Yang et al., 2016) were independently reported to affect both starch and amylopectin contents in fresh waxy corn. Thus, determining the suitable growing season for hybrid seed production and extended field trials emphasizing on carbohydrate composition in fresh kernel of sweet-waxy corn hybrids are encouraged.

Table 2. North Carolina II analysis for kernel carbohydrate components of $24 \mathrm{~F}_{1}$ progenies evaluated across two seasons between 2017 and 2018

\begin{tabular}{|c|c|c|c|c|c|c|c|c|}
\hline \multirow{2}{*}{ Source } & \multirow{2}{*}{$d f$} & \multicolumn{7}{|c|}{ Mean squares } \\
\hline & & TSU & SUC & GLU & FRU & PHY & TSA & AMY \\
\hline Season $(\mathrm{S})$ & 1 & $2,241.1 * *$ & $940.6 * *$ & $9.8 \mathrm{~ns}$ & $183.4 * *$ & $138.3 * *$ & $238,971.2 * *$ & $227,799.1 * *$ \\
\hline Hybrids (H) & 23 & $386.1 * *$ & $13.7 * *$ & $95.2 * *$ & $46.6 * *$ & $3.1 * *$ & $860.6^{* *}$ & $726.9 * *$ \\
\hline $\mathrm{GCA}_{\mathrm{F}}$ & 2 & $686.2 * *$ & $32.0 * *$ & $182.9 * *$ & $53.6^{* *}$ & $1.1^{*}$ & $2,018.7 * *$ & $499.1 \mathrm{~ns}$ \\
\hline $\mathrm{GCA}_{M}$ & 7 & $633.0 * *$ & $23.1 * *$ & $137.8 * *$ & $84.7 * *$ & $4.4^{* *}$ & $1,225.2 * *$ & $1,143.4 * *$ \\
\hline $\mathrm{SCA}$ & 14 & $219.7 * *$ & $6.4^{* *}$ & $61.3 * *$ & $26.5^{* *}$ & $2.7 * *$ & $512.9 * *$ & $551.2 *$ \\
\hline $\mathrm{H} \times \mathrm{S}$ & 23 & $308.4 * *$ & $9.0 * *$ & $81.1 * *$ & $50.7 * *$ & $1.5 * *$ & $628.2 * *$ & $549.1 *$ \\
\hline $\mathrm{GCA}_{\mathrm{F}} \times \mathrm{S}$ & 2 & $829.5 * *$ & $13.5^{* *}$ & $172.8 * *$ & $184.2 * *$ & $1.1^{*}$ & $1,812.0 * *$ & $1,260.2 *$ \\
\hline $\mathrm{GCA}_{M} \times \mathrm{S}$ & 7 & $272.7 * *$ & $5.6 * *$ & $97.0 * *$ & $35.5^{* *}$ & $2.0 * *$ & $806.0^{* *}$ & $627.0 \mathrm{~ns}$ \\
\hline $\mathrm{SCA} \times \mathrm{S}$ & 14 & $251.8 * *$ & $10.0 * *$ & $60.0 * *$ & $39.3 * *$ & $1.3 * *$ & $370.2 \mathrm{~ns}$ & $408.5 \mathrm{~ns}$ \\
\hline Pooled error & 92 & 22.6 & 0.6 & 6.7 & 3.8 & 0.3 & 221.1 & 315.4 \\
\hline$\%$ SS GCA $A_{F}$ & & 15 & 20 & 17 & 10 & 3 & 21 & 6 \\
\hline$\%$ SS GCAM & & 50 & 52 & 44 & 55 & 44 & 43 & 48 \\
\hline$\%$ SS SCA & & 35 & 28 & 39 & 35 & 53 & 36 & 46 \\
\hline $\mathrm{h}_{\mathrm{ns}}^{2}(\%)$ & & 63 & 61 & 57 & 61 & 19 & 74 & 62 \\
\hline
\end{tabular}

TSU total sugar, SUC sucrose, GLU glucose, FRU fructose, PHY phytoglycogen, TSA total starch, AMY amylopectin; $d f$ degrees of freedom, GCA general combining ability of female parent, $\mathrm{GCA}_{\mathrm{M}}$ general combining ability of male parent, SCA specific combining ability, \%SS proportional contribution of sum of squares, $\mathrm{h}_{\text {ns }}^{2}$ narrow-sense heritability; * and ** significant at $\mathrm{P}<0.05$ and $\mathrm{P}<0.01$, respectively, ns not significant at $\mathrm{P}<0.05$.

The effects of GCA and SCA were significant for all observed traits except for AMY (Table 2); however, the proportion of GCA expressed by percentage of sum of squares was greater than that of SCA for all observed traits except for PHY, indicating the predominance of additive gene effect for these traits. This finding corroborated previous reports on sugar components in temperate sweet corn lines (Rosenbrook and Andrew, 1971) and starch properties of pasting viscosity in tropically adapted waxy corn lines (Ketthaisong et al., 2014). Both greater GCA and additive effects on TSU, GLU, SUC, FRU, TSA, and AMY indicated the more favorable alleles (sh2, bt, and $w x)$ shared among parental lines. The absence of additive gene effect for PHY trait was caused by a lack of responsible recessive allele sul among parents used. Phytoglycogen (PHY) was greatly accumulated in the corn endosperm containing gene sugary-1 (sul) (Ayers and Creech, 1969; Black et al., 1966). Narrow-sense heritability $\left(h^{2}{ }_{n s}\right)$ estimates was moderate $(57 \%-74 \%)$ for all traits of interest except for PHY (19\%). The overwhelming additive gene effect with moderate heritability estimates suggested that breeders might obtain rapid breeding values by conducting phenotypic selection at early generations.

\section{General combining ability (GCA) and parental mean}

The parental mean and GCA estimates for TSU and the sugar fractions are presented in Table 3, whereas for PHY, TSA, AMY in Table 4. In this study, the selection of sweet and waxy corn lines as parents appealed to consumer preferences on high sweetness, soft tenderness, and stickiness. Favorable sweetness correlated to high TSU, SUC, FRU, and GLU, whereas soft tenderness associated with high PHY. Stickiness was represented by high values of both TSA and AMY. These traits were expressed in both high, positive means and GCA estimates. Two of three female lines, 101LBW and 101LTSC-10, showed overall good general combiners for total sugar and the sugar fractions; however, 101LBW possessed better line per se than the latter. 101LBW had the highest means and positive GCA estimates on TSA (140.0 mg/g; 2.05, P<0.05), SUC (26.3 mg/g; 0.48, $\mathrm{P}<0.01)$, GLU (68.1 mg/g; 1.27, $\mathrm{P}<0.01)$, and FRU (45.5 $\mathrm{mg} / \mathrm{g} ; 0.30, \mathrm{P}>0.05)$. No female with high means and positive GCA estimates for TSA and AMY was noticed. One of eight male lines namely KVMON displayed a good general combiner for TSA $(181.6 \mathrm{mg} / \mathrm{g} ; 14.08$, $\mathrm{P}<0.01)$ and AMY $(177.5 \mathrm{mg} / \mathrm{g} ; 14.00, \mathrm{P}<0.05)$. In contrary with female, no male with high means and positive GCA estimates for total sugar and the sugar fractions was revealed. This finding was expected since the female and male corresponded to sweet corn and waxy corn groups, respectively. 
Table 3. Parental mean and general combining ability (GCA) estimates for total sugar and the sugar fractions of three sweet corn and eight waxy corn inbred lines evaluated across two seasons between 2017 and 2018

\begin{tabular}{|c|c|c|c|c|c|c|c|c|}
\hline \multirow{2}{*}{ Lines } & \multicolumn{2}{|c|}{ Total sugar $(\mathrm{mg} / \mathrm{g})$} & \multicolumn{2}{|c|}{ Sucrose (mg/g) } & \multicolumn{2}{|c|}{ Glucose (mg/g) } & \multicolumn{2}{|c|}{ Fructose (mg/g) } \\
\hline & Mean & GCA & Mean & GCA & Mean & GCA & Mean & GCA \\
\hline \multicolumn{9}{|l|}{ Females } \\
\hline 101LBW & 140.0 & $2.05 *$ & 26.3 & $0.48 * *$ & 68.1 & $1.27 *$ & 45.5 & $0.30 \mathrm{~ns}$ \\
\hline 101LTSC-4 & 108.7 & $-4.36 * *$ & 17.4 & $-0.94 * *$ & 54.7 & $-2.25 * *$ & 36.7 & $-1.17 * *$ \\
\hline 101LTSC-10 & 87.2 & $2.32 *$ & 15.8 & $0.47 * *$ & 42.1 & $0.97 *$ & 29.3 & $0.88^{*}$ \\
\hline \multicolumn{9}{|l|}{ Males } \\
\hline Y18 & 33.8 & $2.30 *$ & 4.2 & $0.64 *$ & 17.2 & $0.95 \mathrm{~ns}$ & 12.3 & $0.71 \mathrm{~ns}$ \\
\hline C13-1 & 39.6 & $8.34 * *$ & 5.7 & $1.61 * *$ & 19.8 & $4.13 * *$ & 14.1 & $2.59 * *$ \\
\hline HNO2 & 20.3 & $-9.15^{* *}$ & 2.6 & $-1.51 * *$ & 10.8 & $-3.99 * *$ & 7.0 & $-3.66 * *$ \\
\hline HJ & 39.2 & $3.46^{*}$ & 3.7 & $-0.08 n s$ & 21.6 & $2.20 *$ & 13.9 & $1.33^{*}$ \\
\hline OWX13 & 32.1 & $-6.43 * *$ & 4.4 & $-1.35 * *$ & 16.3 & $-2.80 * *$ & 11.5 & $-2.27 * *$ \\
\hline KVMON & 33.1 & $-4.11 *$ & 4.0 & $-0.49 *$ & 16.5 & $-2.31 *$ & 12.5 & $-1.31 *$ \\
\hline KV3473 & 30.2 & $3.76^{*}$ & 3.6 & $1.28 * *$ & 14.7 & $0.79 \mathrm{~ns}$ & 11.8 & $1.69^{*}$ \\
\hline KNM102 & 32.7 & $1.83 \mathrm{~ns}$ & 3.2 & $-0.10 \mathrm{~ns}$ & 17.5 & $1.02 \mathrm{~ns}$ & 11.9 & $0.91 \mathrm{~ns}$ \\
\hline LSD 0.05 & 8.1 & & 1.3 & & 4.7 & & 3.2 & \\
\hline SE female & & 1.37 & & 0.23 & & 0.75 & & 0.56 \\
\hline SE male & & 2.24 & & 0.37 & & 1.22 & & 0.91 \\
\hline $\mathrm{r}$ & \multicolumn{2}{|c|}{$0.09 \mathrm{~ns}$} & \multicolumn{2}{|c|}{$0.09 \mathrm{~ns}$} & \multicolumn{2}{|c|}{$0.11 \mathrm{~ns}$} & \multicolumn{2}{|c|}{$0.09 \mathrm{~ns}$} \\
\hline
\end{tabular}

Table 4. Parental mean and general combining ability (GCA) estimates for phytoglycogen, total starch, and amylopectin of three sweet corn and eight waxy corn inbred lines evaluated across two seasons between 2017 and 2018

\begin{tabular}{|c|c|c|c|c|c|c|}
\hline \multirow{2}{*}{ Lines } & \multicolumn{2}{|c|}{ Phytoglycogen (mg/g) } & \multicolumn{2}{|c|}{ Total starch (mg/g) } & \multicolumn{2}{|c|}{ Amylopectin (mg/g) } \\
\hline & Mean & GCA & Mean & GCA & Mean & GCA \\
\hline \multicolumn{7}{|l|}{ Females } \\
\hline 101LBW & 8.7 & $0.09 \mathrm{~ns}$ & 45.4 & $-4.86 *$ & 38.1 & $-2.66 n s$ \\
\hline 101LTSC-4 & 6.4 & $-0.18^{*}$ & 69.0 & $7.37 *$ & 61.1 & $3.59 \mathrm{~ns}$ \\
\hline 101LTSC-10 & 8.5 & $0.09 \mathrm{~ns}$ & 68.5 & $-2.51 \mathrm{~ns}$ & 62.4 & $-0.92 n s$ \\
\hline \multicolumn{7}{|l|}{ Males } \\
\hline Y18 & 4.8 & $0.47 *$ & 157.5 & $-1.51 \mathrm{~ns}$ & 150.7 & $-3.34 \mathrm{~ns}$ \\
\hline C13-1 & 4.7 & $0.57 * *$ & 145.7 & $-9.10^{*}$ & 136.6 & $-9.24 *$ \\
\hline HNO2 & 3.6 & $-0.32 *$ & 151.7 & $-3.46 n s$ & 143.4 & $-0.08 n s$ \\
\hline $\mathrm{HJ}$ & 4.8 & $0.49 *$ & 121.9 & $-11.42 *$ & 105.8 & $-10.51 *$ \\
\hline OWX13 & 3.9 & $-0.44 *$ & 132.4 & $5.66 \mathrm{~ns}$ & 126.3 & $5.89 \mathrm{~ns}$ \\
\hline KVMON & 4.1 & $0.23 \mathrm{~ns}$ & 181.6 & $14.08 * *$ & 177.5 & $14.00 *$ \\
\hline KV3473 & 4.1 & $-0.31 *$ & 165.6 & $1.77 \mathrm{~ns}$ & 153.7 & $2.54 \mathrm{~ns}$ \\
\hline KNM102 & 4.2 & $-0.70 * *$ & 122.2 & $3.98 \mathrm{~ns}$ & 104.7 & $0.73 \mathrm{~ns}$ \\
\hline LSD 0.05 & 0.7 & & 12.2 & & 13.5 & \\
\hline SE female & & 0.15 & & 4.29 & & 5.13 \\
\hline SE male & & 0.25 & & 7.01 & & 8.37 \\
\hline $\mathrm{r}$ & \multicolumn{2}{|c|}{$0.21 \mathrm{~ns}$} & \multicolumn{2}{|c|}{$0.50 \mathrm{~ns}$} & \multicolumn{2}{|c|}{$0.59 \mathrm{~ns}$} \\
\hline
\end{tabular}

The correlation coefficients ( $r$ ) between parental mean and GCA estimates were not significant for all observed traits, ranging from poor on TSU (0.09), SUC (0.09), GLU (0.11), FRU (0.09), low on PHY (0.21), and medium on TSA (0.50), and AMY (0.59). This evidence indicated that selection of parental lines based solely on line per se was not recommended especially for sugar contents. For example, in sweet corn lines assigned as female, 101LTSC-4 had higher mean but lower GCA estimates of TSA, SUC, GLU, and FRU than 101LTSC-10. In this study, none of parental lines used was completely superior for each carbohydrate components. Although recessive allele $w x$ has been equipped in all tested sweet corn lines, the expression was masked by either $s h 2$ or $b t$ gene, well known as epistatic effect (Boyer and Hannah, 2001; Creech, 1965). Both 101LBW and 101LTSC-10 could be assigned as broad-based testers for total sugar and the sugar fractions, whereas KVMON for total starch and amylopectin. 101LTSC-10 and KVMON possessed half pedigree from temperate USA, indicating that the use of 
exotic germplasm followed by some cycles of recurrent selection could improve the genetic gains of local genotypes.

\section{Trait associations among kernel carbohydrate components}

Total starch (TSA) was significantly correlated with AMY ( $\mathrm{r}=0.98, \mathrm{P}<0.01)$. Total sugar (TSU) had strong, positive correlations with GLU $(\mathrm{r}=0.99, \mathrm{P}<0.01)$, FRU ( $\mathrm{r}$ $=0.99, \mathrm{P}<0.01)$, and SUC $(\mathrm{r}=0.98, \mathrm{P}<0.01)$. The strong, positive correlations were also noticed among sugar fractions namely between SUC and GLU ( $r=0.97$, $\mathrm{P}<0.01)$, SUC and FRU $(\mathrm{r}=0.97, \mathrm{P}<0.01)$, and FRU and GLU ( $r=0.99, \quad \mathrm{P}<0.01)$. Phytoglycogen (PHY) was significantly correlated with TSU, GLU, FRU, and SUC with moderate, positive coefficients ranging from 0.73 to 0.75. Both TSA and AMY had significant, negative correlations with TSU, SUC, FRU, and GLU with medium $(\mathrm{r}=-0.66, \mathrm{P}<0.01)$ to high $(\mathrm{r}=-0.85, \mathrm{P}<0.01)$ coefficients.

Our study used sufficient sample size $(\mathrm{n}=38)$ to estimate trait linear associations, consisting of normal waxy corn inbreds, supersweet corn inbreds, and sweetwaxy corn hybrids. As the total sugar increased, other sugar fractions like glucose, fructose, and sucrose increased; thus, suggesting breeders to use total sugar as a quantitative parameter in simultaneous selection for sweetness. Glucose, fructose, and sucrose are three of four sugar fractions composing total sugar in corn (King et al., 2017). These sugar fractions are expressed as the effects of different structural genes i.e. $s h l$ and $b t$ for the respective enzyme activities within the same class mutants in starch biosynthesis pathway (Boyer and Hannah, 2001), explaining the strong, positive correlations among them. Amylopectin mainly constituted about three fourth of normal starch and up to $95 \%$ of waxy starch (Fergason, 2001), revealing a strong, positive correlation between total starch and amylopectin. In carbohydrate synthesis pathway, both shrunken and brittle genes grouped in the first mutant class are epistatic to waxy gene belonged in the second mutant class (Boyer and Hannah, 2001), addressing the negative correlation between starch (TSA, AMY) and sugars (TSU, GLU, FRU, SUC).

\section{Cluster analysis based on hybrid performance}

A dendogram based on amylopectin, total sugar, and phytoglycogen clustered 38 corn genotypes into seven major groups denoted from group A to $G$ (Figure 2). There was only a sweet corn inbred 101LBW in group A, having the lowest amylopectin and the highest values of both total sugar and phytoglycogen. Group B covered two sweet corn inbreds 101LTSC-4 and 101LTSC-10, having low amylopectin and high values of both sugar and phytoglycogen. Group C comprised four waxy corn inbreds Y18, KV3473, HNO2, and KVMON, having high amylopectin, low total sugar, and moderate phytoglycogen. Group D consisted of three sweet-waxy corn $F_{1}$ progenies 101LTSC-4/Y18, 101LTSC4/OWX13, and 101LTSC-10/KVMON, possessing high amylopectin, moderate total sugar, and high phytoglycogen. There were seven corn genotypes in group E including three waxy corn inbreds (C13-1, OWX13, and $\mathrm{HJ})$, two $\mathrm{F}_{1}$ progenies (101LTSC-4/HNO2 and 101LTSC-10/HNO2), and a hybrid check KNW. This group had moderate amylopectin, low total sugar, and moderate phytoglycogen. Group F was the largest group with eleven $\mathrm{F}_{1}$ progenies (101LBW/HNO2, 101LTSC-10/KNM102, 101LBW/KVMON, 101LTSC-4/KVMON, 101LBW/KV3473, 101LBW/KNM102, 101LTSC10/Y18, 101LBW/OWX13, 101LTSC-4/KV3473, 101LTSC-4/KNM102, 101LTSC-10/OWX13) and a check (NTT), having moderate values of both amylopectin and total sugar and low to poor phytoglycogen. Group $\mathrm{G}$ comprising eight $F_{1}$ progenies (101LBW/Y18, 101LTSC10/C13-1, 101LTSC-10/KV3473, 101LBW/HJ, 101LBW/C13-1, 101LTSC-10/HJ, 101LTSC-4/HJ, and 101LTSC-4/C13-1) and a check (SW25) had moderate amylopectin and high values of both total sugar and phytoglycogen.

Hybrid selection was directed to meet consumer preferences on high sweetness, soft tenderness, and stickiness. Since combining both sweetness and stickiness in a single kernel of vegetable corn is impossible due to epistatic effect of gene controlling sweetness (bt, sh2) over waxy gene (wx) (Boyer and Hannah, 2001), the possible way of eating quality improvement is to maximize the proportion of sweet kernels among segregating $F_{2}$ kernels of individual $F_{1}$ ear (Lertrat and Thongnarin, 2008; Simla et al., 2016). We favored a hybrid group with balance proportions of AMY, TSU, and PHY as high as possible to obtain. Grouping of all corn genotypes in this study based on AMY, TSU, and PHY was reliable since the extreme genotypes either waxy corn inbreds with high AMY or waxy corn inbreds with high TSU and PHY were placed in different major groups. The rest groups (D, E, F, and $\mathrm{G}$ ) were sweet-waxy corn $\mathrm{F}_{1}$ progenies, having significantly divergent compositions of AMY, TSU, and PHY (Table 5). Appealing consumer preferences is quite challenging since the parameters of eating quality in vegetable corn are complex that cannot be considered by an attribute alone. Also, three hybrid checks used were clustered in separate groups, indicating preferability of consumers was diverse. Although group $G$ was chosen as representative ideal sweet-waxy corn hybrids due to balance proportions of kernel carbohydrates, other $F_{1}$ progenies in group $\mathrm{E}$ and $\mathrm{F}$ should not be omitted from selection because their performances were similar to the respective checks. Therefore, further investigation of sensory blind test to validate consumer acceptance among sweet-waxy corn tested hybrids is encouraged. 


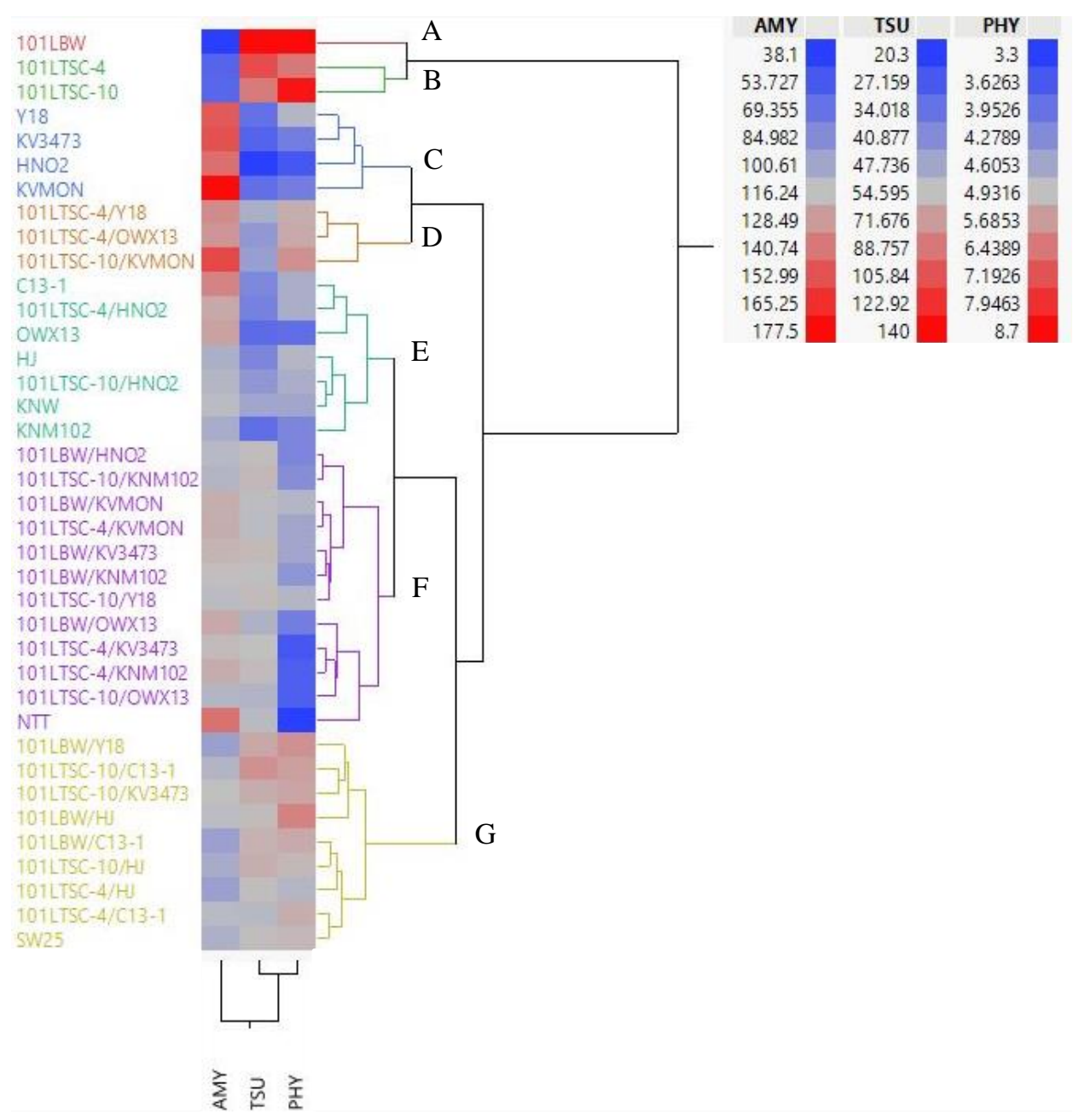

Figure 2. Dendogram of genetic relationships among 3 sweet corn inbreds, 8 waxy corn inbreds, 24 sweet-waxy corn F1 progenies, and 3 hybrid checks, constructed by hierarchical Ward's clustering method based on amylopectin (AMY), total sugar (TSU), and phytoglycogen (PHY). Different line color represents different major group.

Table 5. Major group means of 24 sweet-waxy corn $F_{1}$ progenies derived from cluster analysis based on amylopectin, total sugar, and phytoglycogen

\begin{tabular}{cccccc}
\hline \multicolumn{2}{c}{ Genotypes/Groups } & $\mathbf{N}^{\text {a }}$ & Amylopectin $(\mathbf{m g} / \mathbf{g})$ & Total sugar $\mathbf{( m g / g )}$ & Phytoglycogen $(\mathbf{m g} / \mathbf{g})$ \\
\hline Groups & & & & \\
& D & 3 & $140.23 \pm 14.53$ & $46.53 \pm 3.13$ & $5.53 \pm 0.32$ \\
E & 2 & $117.40 \pm 10.04$ & $40.80 \pm 4.10$ & $4.70 \pm 0.00$ \\
F & 11 & $117.38 \pm 5.39$ & $54.98 \pm 2.58$ & $4.25 \pm 0.44$ \\
G & 8 & $105.94 \pm 8.27$ & $61.84 \pm 7.40$ & $5.48 \pm 0.44$ \\
\hline
\end{tabular}

\begin{tabular}{|c|c|}
\hline \multicolumn{2}{|l|}{ Checks } \\
\hline KNW & 113.20 \\
\hline NTT & 142.80 \\
\hline SW25 & 106.50 \\
\hline${ }^{\mathrm{b}} \operatorname{LSD} 5 \%$ & 22.16 \\
\hline \multicolumn{2}{|c|}{$\begin{array}{l}\text { a only sweet-waxy corn F1 progenies are included (the genotype means } \\
\text { critical value to compare each major group mean to the checks. }\end{array}$} \\
\hline \multicolumn{2}{|c|}{ CONCLUSIONS } \\
\hline \multicolumn{2}{|c|}{$\begin{array}{l}\text { Additive gene effect was responsible for total sugar, } \\
\text { sugar fractions, total starch, and amylopectin, whereas } \\
\text { non-additive gene effects for phytoglycogen of sweet- } \\
\text { waxy corn lines. The use of exotic germplasm contributed } \\
\text { to better GCA estimates and hybrid performance. We } \\
\text { proposed 101LBW and 101LTSC-10 as broad-based }\end{array}$} \\
\hline
\end{tabular}

testers for total sugar and the sugar fractions, and KVMON for total starch and amylopectin. Cluster analysis based on amylopectin, total sugar, and phytoglycogen was reliable to discriminate all corn genotypes into seven major groups. Two of eight $F_{1}$ progenies in group $\mathrm{G}$ namely 101LTSC-10/C13-1 and 101LTSC-10/KV3473 were identified as sweet-waxy corn 
hybrids with excellent, balance proportion of favored carbohydrate components.

\section{ACKNOWLEDGMENTS}

The authors are highly grateful to the Plant Breeding Research Center for Sustainable Agriculture, Faculty of Agriculture, Khon Kaen University, Thailand and the National Science and Technology Development Agency for technical and financial supports. This acknowledgement is extended to the Thailand Research Fund for providing partial financial support through the Senior Research Scholar Project of Prof. Dr. Sanun Jogloy (Project no. RTA 6180002).

\section{LITERATURE CITED}

Ayers, J.E. and R.G. Creech. 1969. Genetic control of phytoglycogen accumulation in maize (Zea mays L.). Crop Sci. 9:739-741.

Azanza, F., B.P. Klein and J.A. Juvik. 1996a. Sensory characterization of sweet corn lines differing in physical and chemical composition. J. Food. Sci. 61(1): 253-257.

Azanza, F., A. Bar-Zur and J.A. Juvik. 1996b. Variation in sweet corn kernel characteristics associated with stand establishment and eating quality. Euphytica 87: 7-18.

Bailey, D.M. and R.M. Bailey. 1938. The relation of the pericarp to tenderness in sweet corn. Proc. Amer. Soc. Hort. Sci. 36:555-559.

Black, R.C., J.D. Loerch, F.J. McArdle and R.G. Creech. 1966. Genetic interactions affecting maize phytogiycogen and the phytoglycogen-forming branching enzyme. Genetics 53: 661-668.

Boyer, C.D. and L.C. Hannah. 2001. Kernel mutants of corn. In Specialty Corns: Second Edition, ed. Hallauer, A.R., 10-40, CRC Press, Boca Raton, London, New York, Washington DC.

Comstock, R.E. and H.F. Robinson. 1948. The components of genetic variance in populations of biparental progenies and their use in estimating the average degree of dominance. Biometrics 4: 254-266.

Creech, R.G. 1965. Genetic control of carbohydrate synthesis in maize endosperm. Genetics 52: 1175-1186.

Falconer, D.S. 1989. Introduction to Quantitative Genetics. London: Oliver and Boyd.

Fergason, V. 2001. High amylose and waxy corns. In Specialty Corns: Second Edition, ed. Hallauer, A.R., 71-92, CRC Press, Boca Raton, London, New York, Washington DC.

Flora, L.F. and R.C. Wiley. 1974. Sweet corn aroma, chemical components, and relative importance in the overall flavor response. J. Food Sci. 39: 770-773.

Gomez, K.A. and A.A. Gomez. 1984. Statistical Procedure for Agricultural Research. Singapore: John Wiley and Sons.

Hallauer, A.R., M.J. Carena and J.B. Miranda Filho. 2010 Quantitative Genetics in Maize Breeding. New York: Springer.

Has, V. and I. Has. 2009. Genetic inheritance of some important characters of sweet corn. Notulae Botanicae Horti Agrobotanici Cluj-Napoca 37: 244-248.

Holland, J.B., W.E. Nyquist and C.T. Cervantez-Martínez. 2003. Estimating and interpreting heritability for plant breeding: An update. Plant Breed. Rev. 22: 2-112.

Jung, T.W., S. Song, B.Y. Son, J.T. Kim, S.B. Baek, C.K. Kim, S.L. Kim, S.J. Kim, S.K. Kim, K.J. Park, H.M. Shin and C.S. Huh. 2009. A black waxy hybrid corn, "Heukjinjuchal" with good eating quality. Korean J. Breed. Sci. 41(4): 599-602.
Jung, T.W., S.L. Kim, H.G. Moon, B.Y. Son, S.J. Kim and S.K. Kim. 2005. Major characteristics related on eating quality and classification of inbred lines of waxy corn. Korean J. Breed. Sci. 50: 161-166.

Ketthaisong, D., B. Suriharn, R. Tangwongchai and K. Lertrat. 2014. Combining ability analysis in complete diallel cross of waxy corn (Zea mays var. ceratina) for starch pasting viscosity characteristics. Sci. Hortic. 175:229-235.

Khanduri, A., B.M. Prasanna, F. Hossain and P.C. Lakhera. 2010. Genetic analyses and association studies of yield components and kernel sugar concentration in sweet corn. Indian J. Genet. 70(3): 257-263.

King, D.L., B. Jasthi and J. Pettit. 2017. Appendix 1Composition of grains and grain products. In Cereal Grains, ed. Wrigley, C., Batey, I., Miskelly, D., 727-750, Woodhead Publishing, Duxford.

Lertrat, K. and N. Thongnarin. 2008. Novel approach to eating quality improvement in local waxy corn: improvement of sweet taste in local waxy corn variety with mixed kernels from super sweet corn. Acta Hortic. 769: 145-150.

Lu, D., X. Sun, F. Yan, X. Wang, R. Xu and W. Lu. 2013. Effects of high temperature during grain filling under control conditions on the physicochemical properties of waxy maize flour. Carbohydr. Polym. 98(1): 302-310.

Menkir, A., M.O. Olowolafe, I. Ingelbrecht, I. Fawole, B. BaduApraku and B.I. Vroh. 2006. Assessment of testcross performance and genetic diversity of yellow endosperm maize lines derived from adapted $\times$ exotic backcrosses. Theor. Appl. Genet. 113: 90-99.

Reyes, F.G.R., G.W. Varseveld and M.C. Kuhn. 1982. Sugar composition and flavour quality of high sugar (shrunken) and normal sweet corn. J. Food Sci. 47:753-755.

Rodríguez, F., G. Alvarado, A. Pacheco, J. Crossa and J. Burgueño. 2018. AGD-R (Analysis of Genetic Designs with $\mathrm{R}$ for Windows) version 5.0. Mexico: International Maize and Wheat Improvement Center.

Rojas, B.A. and G.F. Sprague. 1952. A comparison of variance components in corn yield traits; general and specific combining abilities and their interaction with locations and years. Agron. J. 44: 462-466.

Rosenbrook, R.W. and R.H. Andrew. 1971. Diallel analyses of kernel carbohydrates in sweet corn (Zea mays L.). Crop Sci. 11(4): 536-538.

SAS Institute Inc. 2009. JMP trial 15.0.0 (403428), www.jmp.com, (Accessed January 15, 2020).

Simla, S., K. Lertrat and B. Suriharn. 2016. Combination of multiple genes controlling endosperm characters in relation to maximum eating quality of vegetable waxy corn. SABRAO J. Breed. Genet. 48: 210-218.

Simla, S., K. Lertrat and B. Suriharn. 2009. Gene effects of sugar compositions in waxy corn. Asian J. Plant Sci. 8: 417424.

Simla, S., K. Lertrat and B. Suriharn. 2010. Carbohydrate characters of six vegetable waxy corn varieties as affected by harvest time and storage duration. Asian J. Plant Sci. 9: 463470.

Singh, R.K. and B.D. Chaudhary. 1985. Biometrical Methods in Quantitative Genetic Analysis. New Delhi: Kalyani Publishers.

So, Y.S. 2019. Pericarp thickness of Korean maize landraces. Plant Genet. Resour-C. 17(1): 87-90.

Sprague, G.F. and L.A. Tatum. 1942. General vs. specific combining ability in single crosses of corn. J. Amer. Soc. Agron. 34: 923-932.

Stamp, P., S. Eicke, S. Jampatong, H. Le-Huy, C. Jompuk, F. Escher and S. Streb. 2016. Southeast Asian waxy maize (Zea 
mays L.), a resource for amylopectin starch quality types? Plant Genet. Resour. 15: 430-437.

Statistix 10. 2013. Analytical software, http://statistix.com, (Accessed November 20, 2017).

Swiader, J.M., G.W. Ware and J.P. McCollum. 1992. Sweet corn. In Producing Vegetable Crops. 4th ed. Interstate Publ., Inc., 477-494, Danville, Illinois.

Tian, M., G. Tan, Y. Liu, T. Rong and Y. Huang. 2009. Origin and evolution of Chinese waxy maize: evidence from the Globulin-1 gene. Genet. Resour. Crop Ev. 56: 274-255.
Wann, E.V., G.B. Brown and W.A. Hills. 1971. Genetic modification of sweet corn quality. J. Amer. Soc. Hort. Sci. 96:441-444.

Wong, A.D., J.A. Juvik, D.C. Breeden and J.M. Swiader. 1994. Shrunken 2 sweet corn yield and the chemical components of quality. J. Amer. Soc. Hort. Sci. 119(4): 747-755.

Yang, H., Y. Shi, R. Xu, D. Lu and W. Lu. 2016. Effects of shading after pollination on kernel filling and physicochemical quality traits of waxy maize. Crop J. 4: 235-245. 